\begin{tabular}{|c|c|c|c|c|c|}
\hline JRL & Vol. 13 & No.2 & Hal. 96-115 & $\begin{array}{c}\text { Jakarta, } \\
\text { Desember 2020 }\end{array}$ & $\begin{array}{c}\text { p-ISSN : 2085.38616 } \\
\text { e-ISSN : 2580-0442 }\end{array}$ \\
\hline
\end{tabular}

\title{
MATERIAL FLOW ANALYSIS DALAM EVALUASI KUALITAS AIR BUDIDAYA IKAN NILA DENGAN TEKNIK AKUAPONIK
}

\author{
Fuzi Suciati $^{1 *}$, Dwindrata B Aviantara ${ }^{1}$ \\ ${ }^{1}$ Gd. 820 Geostech PUSPIPTEK Serpong, 15314, Provinsi Banten \\ *Penulis korespondensi: fuzi.suciati@bppt.go.id
}

\begin{abstract}
Abstrak
Pertambahan populasi penduduk menyebabkan pengurangan lahan pangan. Namun kebutuhan pangan semakin meningkat dengan pertumbuhan populasi manusia. Situasi tersebut diperparah dengan kegiatan antropogen

ik yang berdampak kepada penurunan kualitas lingkungan yang pada akhirnya menurunkan kualitas pangan yang dihasikan. Pendekatan Material Flow Analysis (MFA) digunakan untuk memperkirakan pengaruh pengelolaan pakan ikan nila $(\mathrm{PO}=$ Pemberian setiap hari pakan, $\mathrm{P} 1=$ Pemberian satu hari pakan - satu hari puasa, P2 = Pemberian dua hari pakan - satu hari puasa dan P3 = Pemberian tiga hari pakan - satu hari puasa) terhadap mutu air bekas budidaya. Dari hasil perhitungan diperoleh skenario P3 memberikan rasio terkecil kebutuhan pakan terhadap bobot ikan total saat panen. Hal ini menyebabkan penurunan mutu air kolam budidaya ikan lebih lambat daripada skenario lain sehingga kekerapan pergantian air menjadi lebih jarang. Kebutuhan volume air budidaya ikan nila dengan skenario P3 adalah paling sedikit, yakni $25 \%$ dari kebutuhan air yang menggunakan teknik business as usual, yakni P0. Dengan skenario P3 air bekas budidaya ikan nila memiliki potensi untuk digunakan dalam budidaya tanaman tomat secara hidroponik. Potensi panen tomat adalah dua kali berdasarkan konsentrasi fosfor. Meski demikian, dari sudut pandang perolehan biomassa ikan pada saat panen, terdapat kelemahan skenario P3. Dalam hal ini skenario P1 memberikan bobot ikan total paling besar pada saat panen.
\end{abstract}

kata kunci : Material Flow Analysis, budidaya ikan nila, budidaya tomat, air bekas budidaya, sustainable consumption and production. 


\title{
MATERIAL FLOW ANALYSIS IN WATER QUALITY EVALUATION OF THYLAPIA CULTURE USING AQUAPONIC TECHNIQUE
}

\begin{abstract}
Population growth leads to a reduction in food land. However, the need for food is increasing with the growth of the human population. This situation is exacerbated by anthropogenic activities that have an impact on environmental quality degradation which in turn reduces the quality of food produced. The Material Flow Analysis (MFA) approach is used to estimate the effect of tilapia feed management $(P O=$ feeding every day, $P 1$ = giving one day of feed - one day of fasting, $P 2=$ giving two days of feed - one day of fasting and $P 3$ = giving three days feed - one day of fasting) on the quality of water used for cultivation. From the calculation, it is obtained that the $P 3$ scenario provides the smallest ratio of feed requirements to total fish weight at harvest. This results in a slower decline in the quality of aquaculture pond water compare to the other scenarios, resulting in less frequent water changes. The required volume for tilapia aquaculture under the P3 scenario is the least, namely $25 \%$ of the required water using the business as usual plan, namely PO. With the P3 scenario, used water tilapia aquaculture has the potential to be used in hydroponic cultivation of tomatoes. The potential for harvesting tomatoes is twice based on the phosphorus level. However, from the point of view of gained fish biomass at harvest time, a weakness in the P3 scenario is revealed. In that case the P1 scenario provides the largest total fish weight at harvest.
\end{abstract}

kata kunci : Material Flow Analysis, tilapia fish farming, tomato cultivation, used water aquaculture, sustainable consumption and production. 


\section{PENDAHULUAN}

Pangan merupakan kebutuhan pokok bagi setiap manusia. Melalui pangan manusia mendapatkan energi untuk beraktivitas serta melanggengkan sistem kehidupan dari generasi ke generasi. Seiring dengan pertumbuhan populasi manusia maka kebutuhan pangan juga semakin meningkat. Akan tetapi sejalan pula dengan perkembangan peradaban manusia yang semakin modern ternyata langsung maupun tidak langsung berpengaruh terhadap ketersediaan pangan baik ditinjau dari segi kuantitas maupun kualitas. Bertambahnya populasi penduduk telah menyebabkan berkurangnya lahan untuk penyediaan pangan. Selain itu kegiatan antropogenik juga menimbulkan cemaran (pollutant) yang berdampak kepada perubahan kualitas lingkungan yang pada akhirnya memengaruhi kualitas pangan yang dihasikan dari lahan pertanian atau perkebunan terkontaminasi. Hal ini masih ditambah dengan dampak perubahan iklim yang menyebabkan banyak lahan pertanian dan perkebunan menghadapi masalah kekeringan sehingga berpotensi menimbulkan kejadian gagal panen.

Menghadapi situasi terkini tersebut banyak pemerintah di berbagai negara membangun program nasional terkait dengan ketahanan pangan (food security) dan keamanan pangan (food safety). Indonesia juga memiliki program nasional serupa. Badan Perencanaan Pembangunan Nasional merencanakan pada tahun 2020 terdapat 5 (lima) program prioritas Rencana Kerja Pemerintah (RKP) yaitu pembangunan manusia dan pengentasan kemiskinan; infrastruktur dan pemerataan wilayah; nilai tambah sektor riil, industrialisasi dan kesempatan kerja; stabilitas pertahanan dan keamanan nasional; serta ketahanan pangan, air, energi dan lingkungan hidup (Avianni 2019). Adapun perencanaan alokasi anggaran (dalam satuan triliun) untuk setiap program tersebut disajikan pada Tabel 1 (Avianni 2019). Menyimak pengelompokan tersebut tampak jelas bahwa ketahanan pangan, air, energi dan lingkungan hidup merupakan persoalan yang saling terkait sehingga memerlukan pendekatan terpadu (holistic) untuk mengelolanya.

Memerhatikan

semakin berkurangnya sumberdaya, semakin terbatasnya luasan lahan serta semakin menurunnya kualitas lingkungan maka konsumsi dan produksi berkelanjutan (sustainable consumption and production*) menjadi kunci agar ketahanan dan keamanan pangan dapat dilaksanakan. Melalui konsep tersebut maka pertimbangan logik terhadap ketersediaan, kemampuan dan keterbatasan sumberdaya harus senantiasa dipikirkan agar proses konsusmsi dan produksi tidak mengganggu kesetimbangan lingkungan yang bersifat tidak dapat balik (irreversible). Pada tahun 1994 dalam Simposium yang berlangsung di Oslo Norwegia (Oslo Sysmposium) bahwa yang dimaksud dengan Sustainable Consumption and Production (SCP) adalah (United Nations 2019):

"the use of services and related products, which respond to basic needs and bring a better quality of life while minimizing the use of natural resources and toxic materials as well as the emissions of waste and pollutants over the life cycle of the service or product so as not to jeopardize the needs of further generations"

Atau

"pemanfaatan jasa serta produk terkait, yang berkaitan dengan kebutuhan dasar dan menggiring perbaikan kualitas hidup yang secara bersamaan meminimalkan penggunaan sumberdaya alam dan bahan beracun serta pelepasan limbah dan cemaran sepanjang daur hidup jasa atau produk tersebut sedemikian rupa sehingga tidak 
mengancam kebutuhan generasi mendatang"

generasi
Tabel 1. Rencana Kerja Pemerintah 2020 beserta perencanaan anggaran ikan nasional. Pola konsumsi ikan nasional untuk periode 2012 - 2017 disajikan pada Gambar 1 (Kementerian Kelautan dan Perikanan 2018). Sebagaimana ditunjukkan pada Gambar

Program Prioritas nasion Angaran nasional pada tahun 50 po terhadap 2012

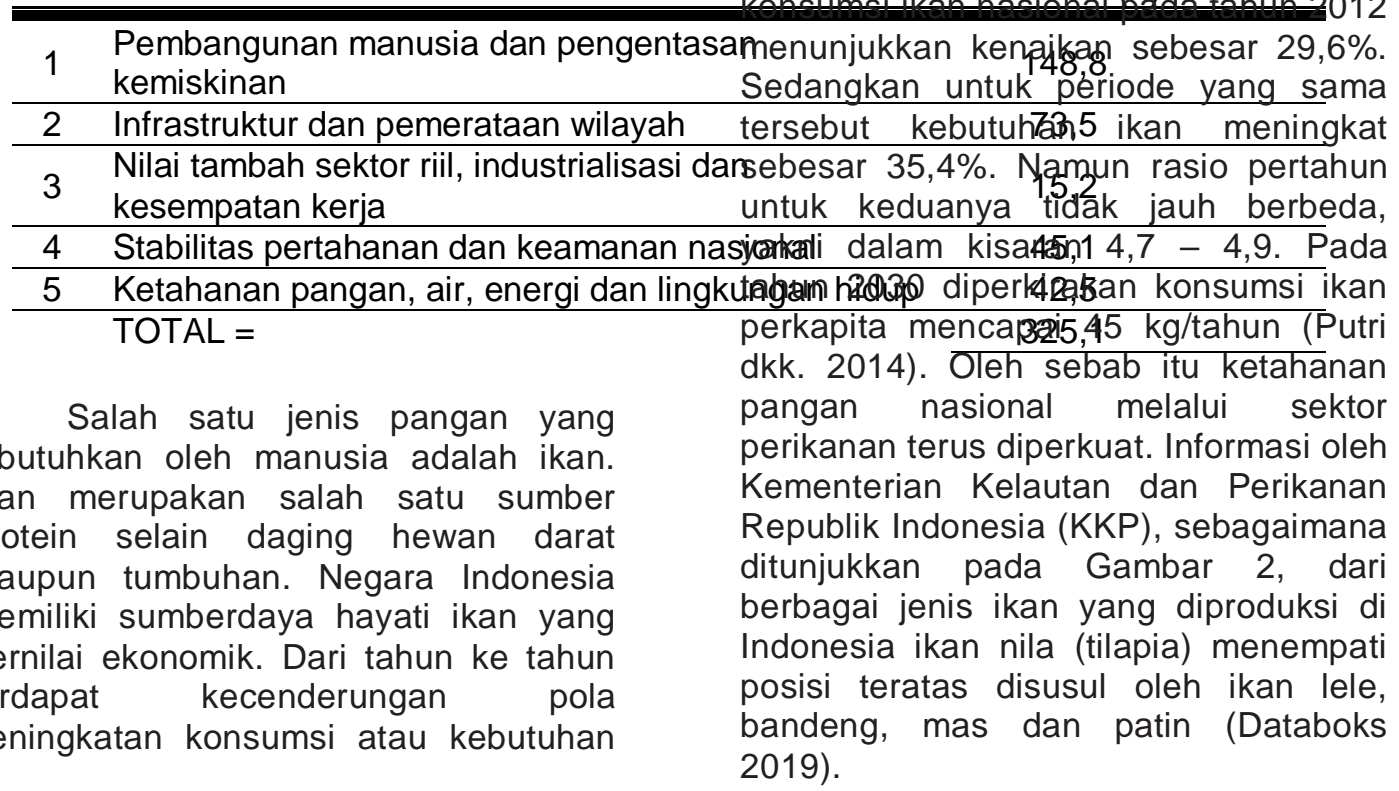

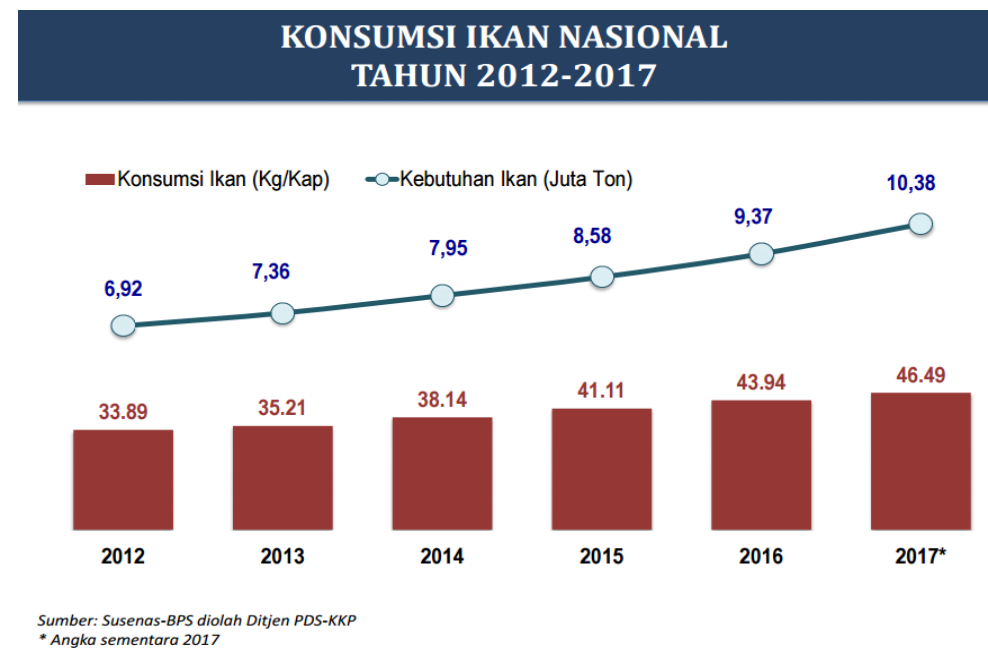

Gambar 1. Pola konsumsi dan kecenderungan kebutuhan ikan nasional periode 2012 2017 


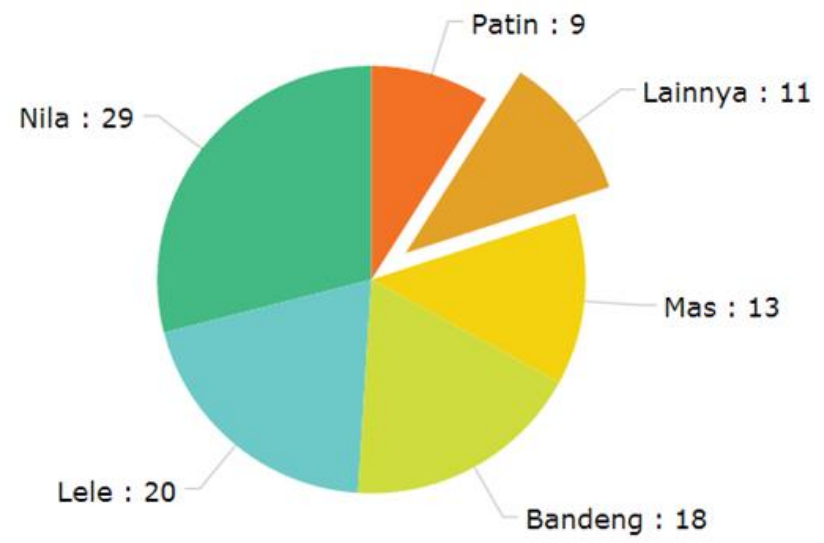

Gambar 2. Informasi KKP produksi perikanan budidaya pada tahun 2015

\section{TUJUAN}

Tulisan ini bertujuan menyajikan pendekatan Material Flow Analysis (MFA) untuk memperkirakan pengaruh pengelolaan pakan ikan serta air budidaya ikan nila (tilapia) terhadap mutu air bekas budidaya dan potensi pemanfaatannya melalui penerapan teknologi akuaponik sebagai upaya merealisasikan konsep sustainable consumption and production (SCP).

\section{METODE}

Dalam menyusun tulisan ini digunakan metode penelusuran informasi sekunder yang diperoleh dari jurnal (nasional dan internasional), laporan teknis, textbook, buku pegangan ( $h a n d b o o k$ ) serta sejumlah sumber lainnya yang dapat diperoleh dari laman internet.

\section{PERMASALAHAN LINGKUNGAN BUDIDAYA IKAN NILA}

Ikan nila (tilapia) memiliki kemampuan bertumbuh dan berkembang cepat serta mudah dibudidayakan (Nugroho dkk. 2013). Ikan nila dapat dibudidayakan pada lingkungan air seperti danau, waduk, rawa dan sungai. Pertumbuhan dan perkembangan ikan nila berlangsung optimal pada kisaran suhu $25-30^{\circ} \mathrm{C}$ serta keasaman medium 7 - 8. Terdapat berbagai jenis ikan nila yang dapat dibudidayakan. Dua jenis yang umum dibudidayakan adalah nila GESIT (Genetically Supermale Indonesian Tilapia) yang dikembangkan oleh Badan Pengkajian dan Penerapan Teknologi (BPPT) serta nila BEST (Bogor Enhanced Strain Tilapia) yang dikembangkan oleh Balai Riset Perikanan Budidaya Air Tawar (BRPBAT) - Kementerian Kelautan dan Perikanan (KKP). Beberapa contoh nila jenis lain, misal GIFT (Genetic Improvement for Farmed Tilapia), yang dapat dibudidayakan diperlihatkan pada Gambar 3 (Muhammad 2018).

Sistem budidaya perikanan darat, termasuk budidaya ikan nila, seringkali menimbulkan persoalan penurunan kualitas lingkungan (Siregar 2016). Salah satu contoh adalah air budidaya yang dibuang ke badan air penerima menyebabkan terjadinya eutrofikasi, yakni pertumbuhan populasi algal secara masif (algal blooming), pada badan air penerima tersebut. Pertumbuhan populasi algal secara masif tersebut menyebabkan penurunan tingkat (level) oksigen terlarut (dissolved oxygen) pada badan air penerima. Hal ini dikarenakan meningkatnya flux pernafasan (respiration flux) oleh alga seiring dengan pertumbuhan populasi alga. Dengan 
menurunnya konsentrasi oksigen terlarut tersebut maka akan merubah keadaan lapisan air permukaan dari oksik (oxic), yakni keadaan lingkungan dengan oksigen berkecukupan, menjadi anoksik (anoxic), yakni keadaan lingkungan dengan oksigen yang sangat minim. Sebagai konsekuensi dari perubahan tersebut adalah terganggunya sistem pernafasan biota lain (misal ikan,

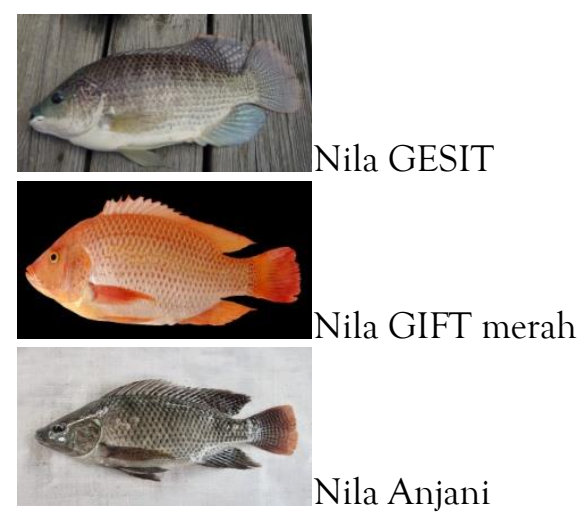

mikroflora dan lain lain). Jika konsentrasi oksigen kurang dari $2 \mathrm{mg} / \mathrm{L}$ maka dapat menyebabkan kematian biota yang lamban laun melalui proses degradasi bahan organik secara anaerobik menyebabkan timbulnya gas serta zat karbon organik atsir (volatile organic carbon) mengandung sulfida yang berbau menyengat dan bersifat racun (toxic).

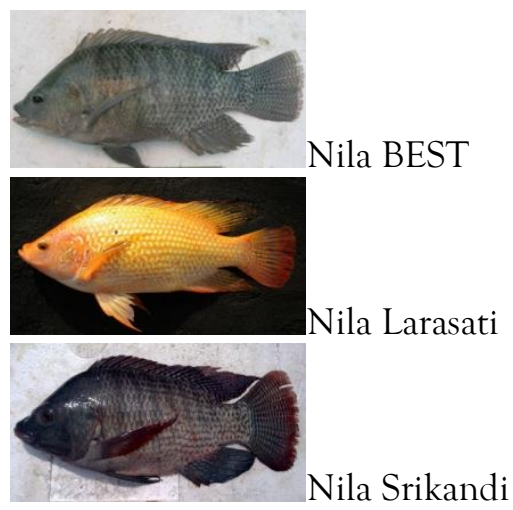

Gambar 3. Berbagai jenis nila yang dibudidayakan

Pertumbuhan populasi algal secara masif dipicu oleh adanya zat hara (nutrient) berlebih yang terdapat dalam air buangan dari budidaya perikanan darat. Zat hara tersebut dapat berupa amonium $\left(\mathrm{NH}_{4}{ }^{+}\right)$, nitrat $\left(\mathrm{NO}_{3}{ }^{-}\right)$maupun fosfat $\left(\mathrm{PO}_{4}{ }^{3-}\right.$ ). Adanya zat hara berlebih dalam air buangan budidaya perikanan darat dikarenakan petambak memberikan pakan ikan berlebih. Jelas bahwa praktek yang demikian tidak selaras dengan konsep Sustainable Consumption and Production (SCP).

Selain persoalan pakan ikan berlebih masalah lain yang sering muncul adalah kekerapan (frequency) penggantian air kolam. Hal ini merupakan pemborosan air dan berlawanan dengan isu global yakni water scarcity yang mengusung kelangkaan atas air sehingga perlu penghematan air. Oleh sebab itu perlu dilakukan terobosan teknologi pengelolaan budidaya ikan, khususnya dalam hal pakan ikan dan penggunaan air.

Salah satu teknik yang dapat dikombinasikan dengan budidaya ikan nila agar selaras dengan konsep Sustainable Consumption and Production (SCP) adalah intergrasi dengan budidaya tanaman hidroponik. Teknik tersebut diterapkan dengan pertimbangan bahwa air buangan budidaya ikan nila masih memiliki zat hara yang dapat dimanfaatkan oleh sistem perakaran tanaman hidroponik. Dalam sistem produksi teknik integrasi yang demikian ini disebut sebagai teknologi akuaponik, yakni kombinasi akuakultur (aquaculture) dan hidroponik (hydroponic). Sedangkan kelompok ahli lingkungan memandang cara tersebut sebagai salah satu penerapan teknologi fitoremediasi (phytoremediation), yakni teknik pemulihan kualitas lingkungan dengan mengandalkan tanaman sebagai 
agensia utama pembersih lingkungan melalui mekanisme penyerapan (absorption) bahan perancu lingkungan (environmental contaminant) oleh sistem perakaran.

\section{AKUAPONIK}

Akuaponik adalah kombinasi sistem budidaya akuakultur dengan sistem hidroponik. Sistem hidroponik merupakan teknik bertanam tanpa menggunakan matriks tanah sebagai medium tumbuh tanaman. Dalam hal ini sistem perakaran tanaman berada dalam keadaan tercelup dalam medium air di mana proses pengambilan zat hara oleh akar berlangsung. Air yang berfungsi sebagai medium di mana akar tanaman memperoleh zat hara dapat berasal dari air limbah budidaya perikanan. Dari sudut pandang luasan lahan yang dibutuhkan dalam budidaya perpaduan ini sangat menguntungkan karena dapat diterapkan pada areal budidaya tanaman maupun perikanan yang terbatas. Daya ungkit (leverage) utama perpaduan tersebut adalah pemanfaatan zat hara dalam limbah sekaligus penghematan pengunaan air (Cohen et.al. 2018).

Terdapat 6 (enam) model sistem akuaponik yang lazim diterapkan (Yonida 2015), yaitu akuaponik tunggal DFT (Deep Flow Technique), akuaponik aliran atas, akuaponik pasang surut, akuaponik kolam bertingkat, akuaponik rak sayuran bertingkat dan akuaponik rakit apung. Berapa contoh dari model sistem akuaponik ditunjukkan pada Gambar 4. Dari contoh beberapa model tersebut secara umum operasional dari sistem akuaponik, dengan memandang budidaya ikan dan budidaya tanaman adalah sistem yang berbeda, dapat merupakan sistem tersambung (coupled) atau sistem terpenggal (decoupled). Sistem tersambung adalah kombinasi akuakultur dan hidroponik di mana air mengalir secara menerus dan berulang. Sedangkan sistem terpenggal jika air yang semula hanya mengalir secara menerus dan berulang dalam sistem akuakultur pada suatu ketika, dengan bantuan pengatur aliran (berupa katup/valve) yang dipasang di antara kedua sistem, dialirkan ke dalam sistem hidroponik sebagai medium tumbuh tanaman (Peterhans 2015). Secara diagram kedua sistem operasional akuaponik tersebut ditunjukkan pada Gambar 5.

Terdapat sejumlah tanaman yang dapat ditumbuhkan dengan teknik akuaponik, di antaranya adalah kangkung, selederi, tomat, bayam merah, sawi, selada hijau, selada merah, daun adas, cabe rawit, cabe merah, kemangi, daun bawang, terong, pare, gambas serta timun (Daun ljo 2017, Bayu 2016).

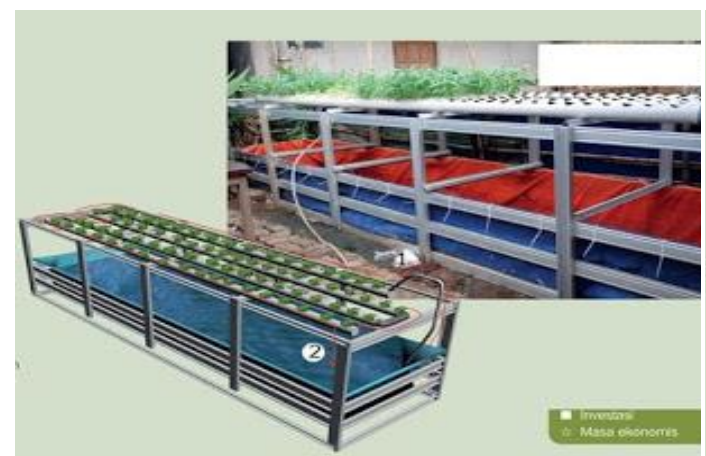

(A)

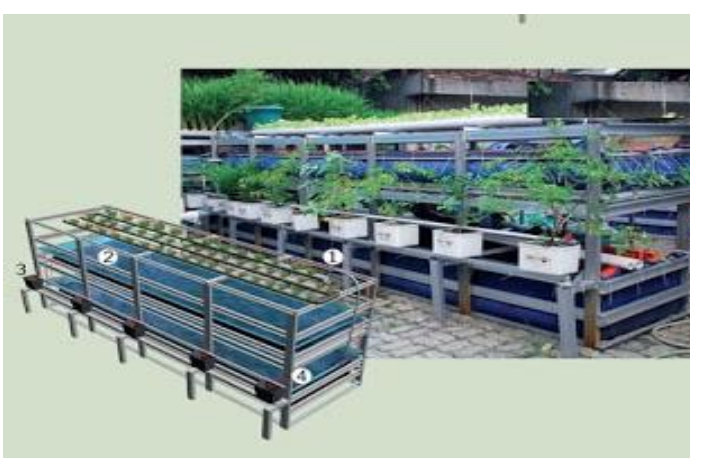

(B) 


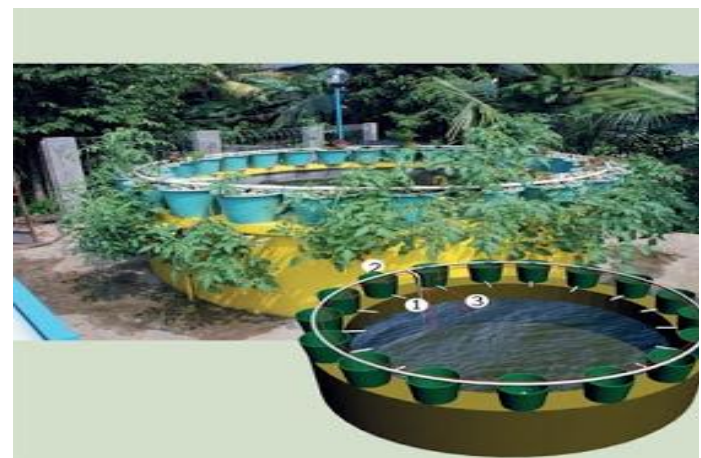

(C)

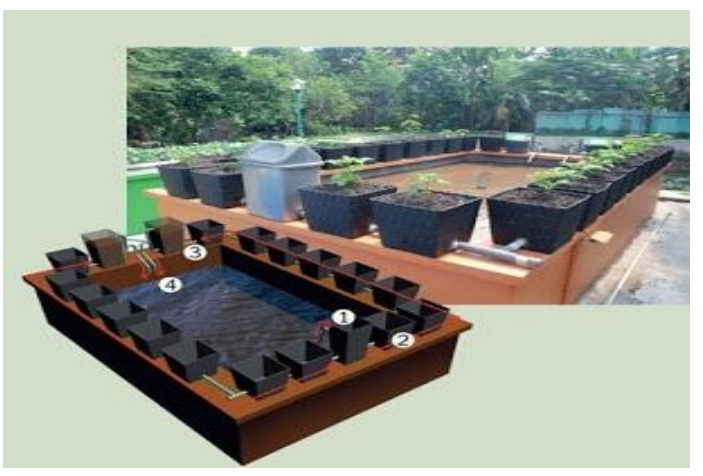

(D)

Gambar 4. Contoh desain atau model akuaponik. (A) DFT, (B) Kolam bertingkat, (C) Aliran atas, dan (D) Pasang surut

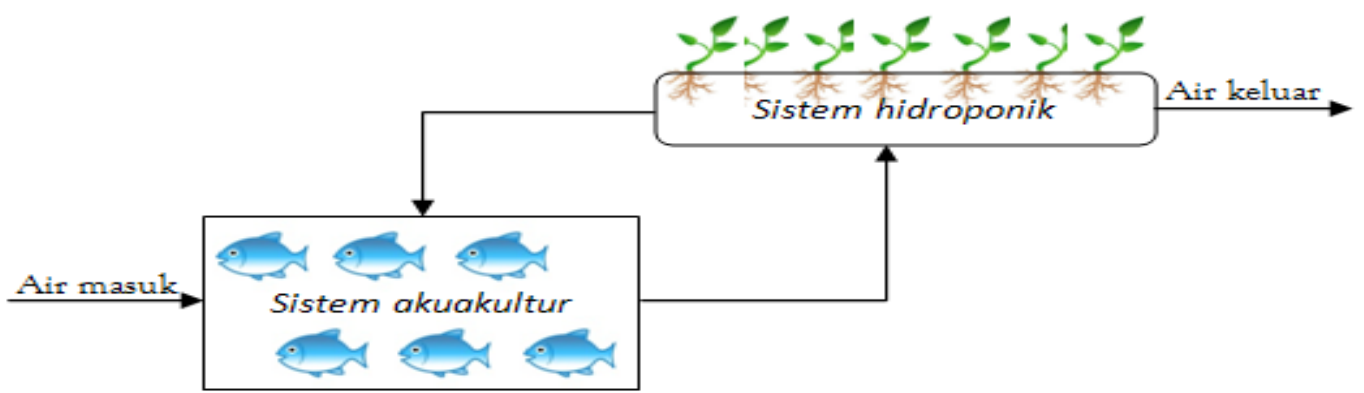

(A)

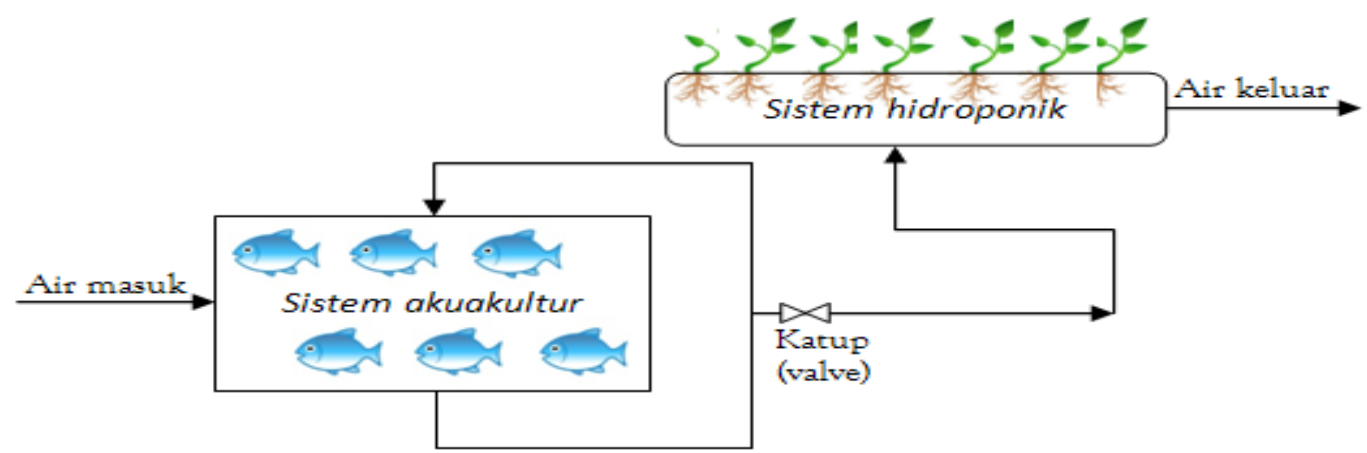

(B)

Gambar 5. Sistem operasional akuaponik: (A) Tersambung dan (B) Terpenggal

\section{PREDIKSI DAYA UNGKIT PENERAPAN TEKNIK AKUAPONIK}

Untuk dapat memperkirakan sejauh mana teknik akuaponik memberikan manfaat perbaikan kinerja lingkungan dalam budidaya, baik nila maupun hidroponik, maka digunakan pendekatan Analisis Aliran Materi
(Material Flow Analysis - MFA). Pendekatan MFA menekankan kepada kaitan antara sumberdaya, lintasan (pathway) serta "sink of materials" berdasarkan prinsip kekekalan materi (Brunner \& Rechberger 2005). Prinsip 
demikian sebenarnya merupakan salah satu prinsip dalam bidang fisika yang telah digagas lebih dari 170 tahun yang lalu, yakni prinsip kekekalan massa (oleh Antoinne Lavoisier pada 1785) dan prinsip kekekalan energi (oleh Julius Robert Mayer pada 1842).

Prediksi daya ungkit penerapan teknik akuaponik dengan pendekatan MFA dilakukan terhadap budidaya ikan nila dengan sistem budidaya sebagai berikut:

- Kapasitas kolam $=40 \mathrm{~m}^{3}$ (dimensi $8 \mathrm{mx}$ $5 \mathrm{~m} \times 1 \mathrm{~m})$

- Kedalaman efektif air kolam $=75 \mathrm{~cm}$ (kisaran normal $60-75 \mathrm{~cm}$ )

- Kepadatan tebar ikan = 25 ekor $/ \mathrm{m} 2$ (kisaran normal 25 - 100 ekor/m2)
- Pompa air (spec: $150 \mathrm{~W}$, debit 50 L/menit)

- Sedangkan perlakuan pemberian pakan adalah 3 (tiga) kali sehari namun dengan pola pemberian pakan sebagaimana berikut ini:

- $P 0=$ Pemberian setiap hari pakan

- $\mathrm{P} 1$ = Pemberian satu hari pakan - satu hari puasa

- $\mathrm{P} 2$ = Pemberian dua hari pakan - satu hari puasa

- $\mathrm{P} 3$ = Pemberian tiga hari pakan - satu hari puasa

Dengan pola perlakuan pemberian pakan tersebut diperoleh data laju pertumbuhan bobot ikan sebagaimana ditunjukkan pada Tabel 2 (Sari dkk. 2017).

Tabel 1. Laju pertumbuhan bobot ikan

\begin{tabular}{ccc}
\hline \hline No & Perlakuan & $\begin{array}{c}\text { Laju pertumbuhan bobot } \\
(\% / \text { hari })\end{array}$ \\
\hline \hline 1 & P0 & 1,43 \\
2 & P1 & 2,32 \\
3 & P2 & 2,05 \\
4 & P3 & 1,49 \\
\hline
\end{tabular}

Budidaya ikan nila secara konvensional menggunakan teknik pergantian air dalam kisaran 1 - 2 minggu untuk menjaga mutu medium air di mana benih ikan nila bertumbuh dan berkembang. Dalam MFA digunakan kekerapan pergantian air setiap seminggu sekali sebagai rujukan perbandingan. Masa panen budidaya ikan nila adalah dalam kisaran $4-6$ bulan sejak penebaran benih ke dalam kolam. Untuk keperluan perhitungan MFA digunakan masa panen 5 bulan sejak penebaran benih dilakukan. Adapun pemberian pakan ikan nila adalah $3 \%$ nisbi (relative) terhadap bobot ikan. Kisaran pemberian pakan ikan yang lazim dilakukan oleh pelaku budidaya ikan nila adalah dalam kisaran $3-7 \%$ dari bobot ikan (Rajagukguk 2018, Salsabilla \& Suprapto 2018, Hartami dkk. 2015, Kusmini $d k k$. 2013). Hal yang terpenting dalam pemberian pakan ikan adalah bukaan mulut ikan dan zat hara atau nutrisi (Marie dkk. 2018). Secara rampatan (general) kebutuhan pakan ikan diperkirakan dari formula:

$$
m_{\text {pakan }}=0,03 * m_{\text {ikan }} * N_{\text {ikan }}
$$

di mana:

$$
\begin{aligned}
& m_{\text {pakan }}=\text { bobot pakan ikan yang } \\
& \text { dibutuhkan }(g) \\
& m_{\text {ikan }}=\text { rataan bobot ikan yang ditebarkan } \\
& \text { dalam kolam (g/ekor) } \\
& N_{\text {ikan }}=\text { jumlah ikan yang ditebarkan dalam } \\
& \text { kolam (ekor) }
\end{aligned}
$$

Untuk budidaya hidroponik yang digunakan adalah tanaman tomat yang ditumbuhkan dalam kolam berukuran $4 \mathrm{~m}$ x $5 \mathrm{~m} \times 0,5 \mathrm{~m}$ (volume $10 \mathrm{~m}^{3}$, kedalaman mangkus (effective) air kolam $=50 \mathrm{~cm}$ ). Tanaman tomat lazimnya dipanen ketika 
tingkat (level) kematangannya berada dalam kisaran 60 - 80\% dengan warna kulit sebagaimana ditunjukkan pada Gambar 6 (Trubus 2014). Secara rampatan masa panen tanam tomat adalah 60 - 90 hari sejak semai benih bila budidaya dilakukan pada lahan. Dengan teknik hidroponik masa panen dapat dilakukan lebih cepat. Untuk keperluan perhitungan MFA ditetapkan masa panen tanaman tomat secara hidroponik adalah 50 hari sejak semai benih. Pemanenan sebelum matang lebih disukai oleh pelaku budidaya karena memperpanjang masa simpan hasil panen

Dengan perlakuan pemberian pakan ikan sebagaimana pada Tabel 2 di atas serta dengan menggunakan persamaan (1) didapatkan pola pertumbuhan bobot ikan total serta kebutuhan pakan ikan sebagai fungsi dari waktu seperti yang diperlihatkan pada Gambar 7. Sedangkan kebutuhan pakan total dan bobot ikan total pada saat panen diperlihatkan pada Gambar 8.
Seperti yang tampak pada Gambar 7 tersebut kebutuhan pakan ikan adalah meningkat selaras dengan pertumbuhan bobot ikan nila. Akan tetapi perolehan bobot ikan total pada saat panen adalah berbeda, seperti yang terlihat pada Gambar 8. Dari empat skenario perlakuan tersebut $P 1$, yakni 1 hari diberi pakan dan 1 hari dipuasakan, memberikan bobot ikan total terbesar pada saat panen di hari ke-150. Bobot ikan total terbesar berikutnya pada saat panen secara berturutan adalah P2, P3 serta P0. Sedangkan urutan kebutuhan pakan ikan dari yang terkecil ke terbesar adalah P0, P3, P2 dan P1. Dari sini tampak jelas bahwa urutan perolehan bobot ikan total saat panen tidak sama dengan urutan kebutuhan pakan ikan. Hal ini disebabkan adanya perbedaan tanggapan (respond) laju pertumbuhan untuk berbagai skenario perlakuan pemberian pakan tersebut. Rasio (ratio) antara kebutuhan pakan ikan total dengan bobot ikan total pada saat panen disajikan pada Tabel 3.

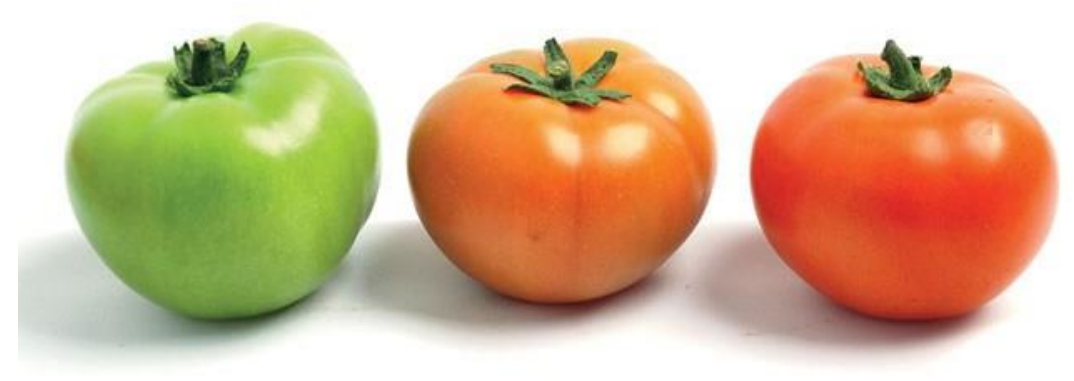

Gambar 6. Tingkat kematangan tomat.

Kiri: $50-60 \%$, tengah: $70-80 \%$, kanan: $>90$ 


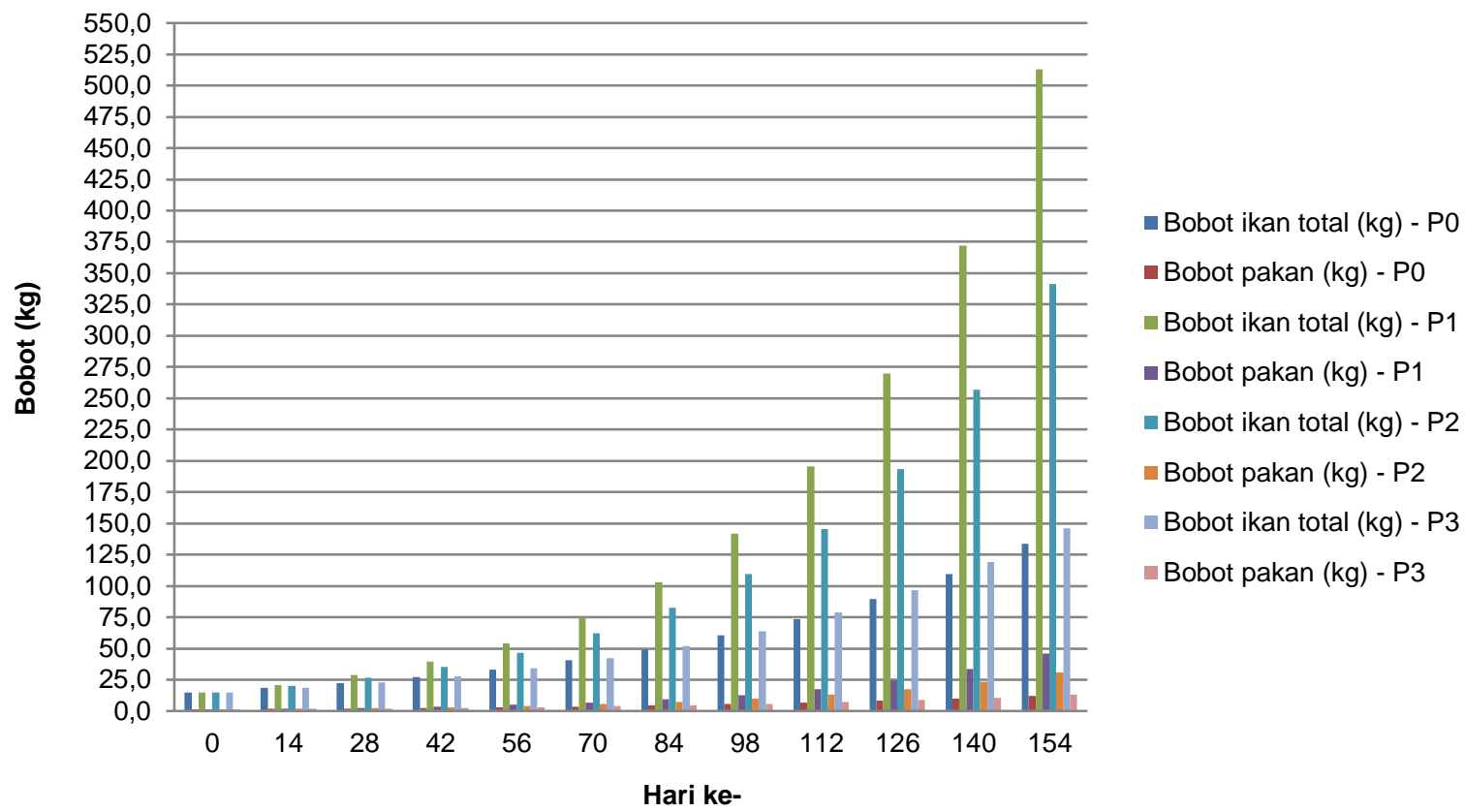

Gambar 7. Pola pertumbuhan bobot ikan total dan kebutuhan pakan

Tabel 3. Rasio kebutuhan pakan ikan total terhadap bobot ikan total saat panen

\begin{tabular}{ccccc}
\hline \hline No & Perlakuan & $\begin{array}{c}\text { Bobot ikan total } \\
(\mathrm{kg})\end{array}$ & $\begin{array}{c}\text { Pakan ikan total } \\
(\mathrm{kg})\end{array}$ & Rasio \\
\hline \hline 1 & P0 & 133,6 & 849,0 & 0,16 \\
2 & P1 & 512,9 & $1.152,9$ & 0,44 \\
3 & P2 & 341,4 & $1.082,9$ & 0,32 \\
4 & P3 & 146,3 & 711,3 & 0,21 \\
\hline
\end{tabular}




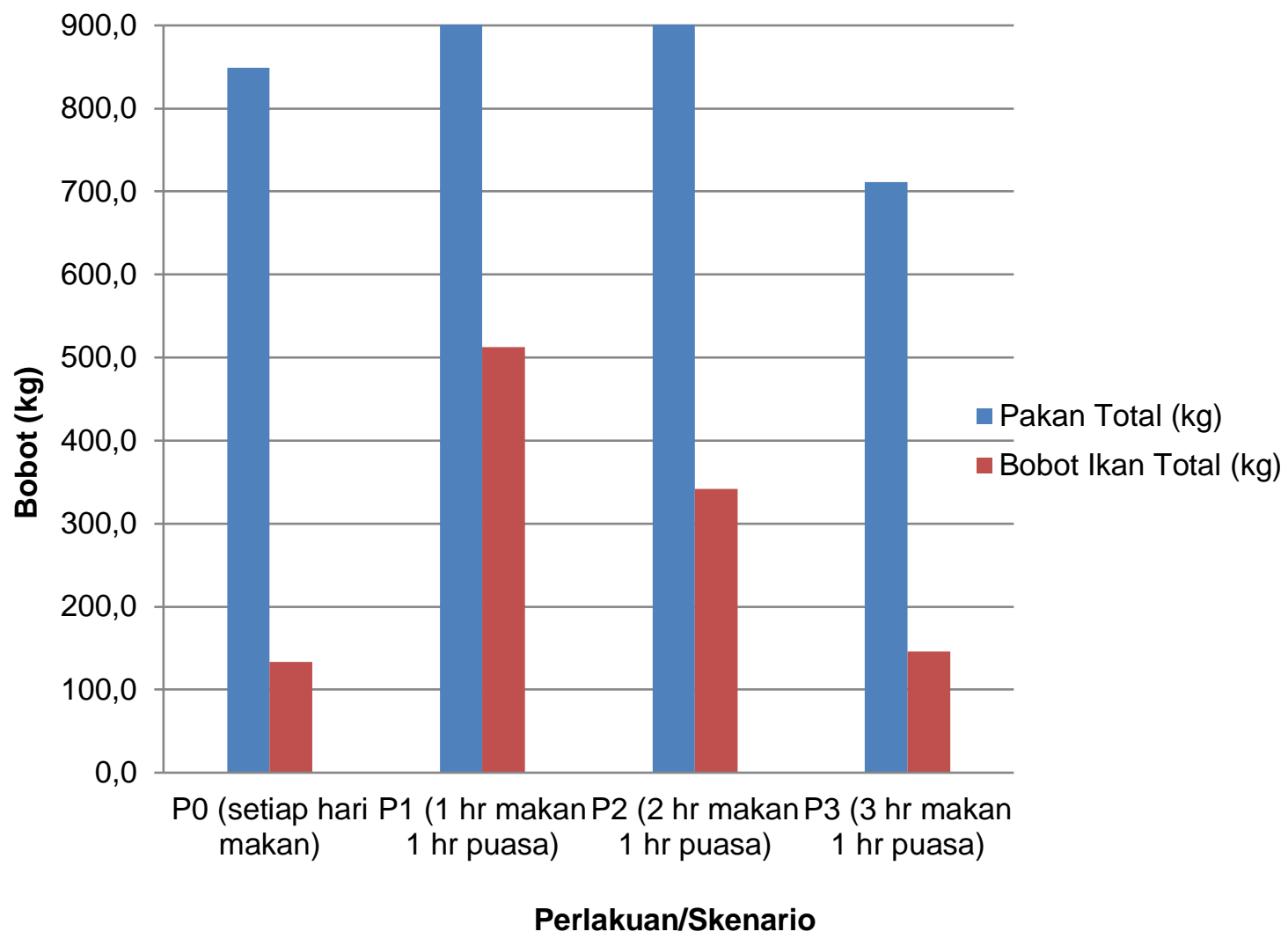

Gambar 8. Kebutuhan pakan total dan bobot ikan total saat panen 


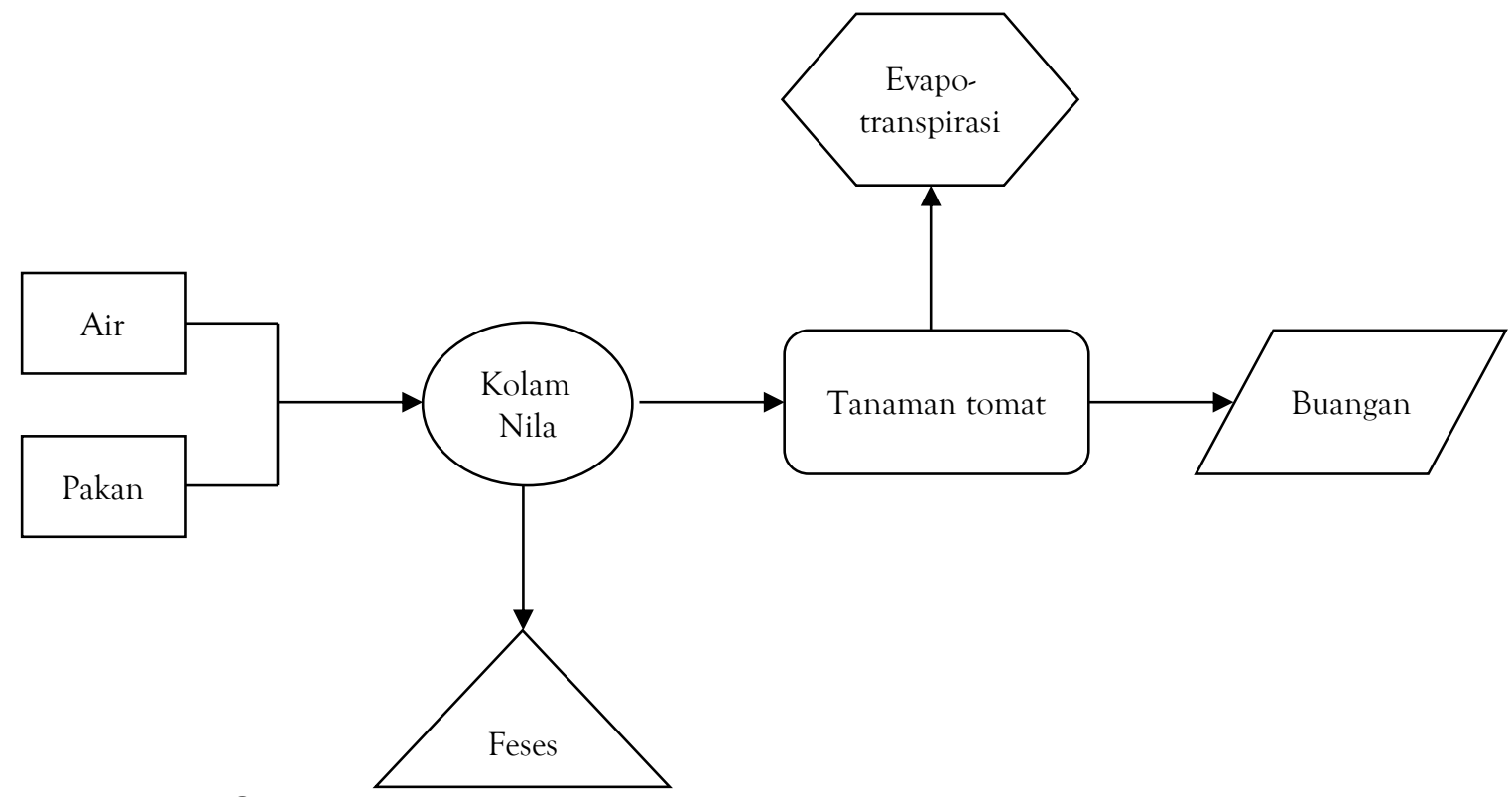

Gambar 9. Model aliran massa dalam sistem akuaponik

Bilamana skenario budidaya hanya mengandalkan kepada aspek perolehan bobot total ikan pada saat panen maka pilihan cara pemberian pakan adalah mengikuti skenario P1 meskipun skenario tersebut membutuhkan pemberian pakan terbesar. Namun apabila rasio kebutuhan pakan ikan total terhadap bobot ikan ikan total pada saat panen menjadi kriteria maka skenario P0 (memberi pakan ikan setiap hari) akan menjadi pilihan. Guna mengevaluasi keempat skenario tersebut maka perlu dipertimbangkan mutu (quality) air kolam sepanjang daur budidaya ikan nila. Hal ini dikarenakan mutu air merupakan kunci dalam menetapkan seberapa sering air kolam perlu diganti. Mutu air kolam untuk budidaya, selain keasaman $(\mathrm{pH})$ dan oksigen terlarut, ditentukan oleh konsentrasi sejumlah komponen zat hara khususnya nitrogen, fosfor dan belerang. Untuk itu diperlukan pendugaan (estimation) terhadap aliran komponen zat hara dalam sistem budidaya ikan nila. Adapun model aliran massa zat hara yang digunakan dalam MFA sistem akuaponik disajikan pada Gambar 9. Perhitungan aliran massa berdasarkan prinsip konservasi massa. Namun sebagai catatan dikarenakan data evapotranspiration flux oleh tanaman tomat belum ada maka kehilangan air terkait mekanisme tersebut tidak dihitung dalam MFA.

Pakan ikan yang ditambahkan ke dalam kolam akan mengalami partisi berdasarkan tiga kompartemen yaitu biomassa ikan, feses ikan serta medium air (pakan yang tidak terserap oleh ikan). Persamaan atau model yang digunakan untuk menghitung konservasi massa adalah (Peterhans 2015):

$m_{\text {air }}=m_{\text {pakan }}-\frac{m_{\text {ikan }}}{F C R}-m_{\text {feses }} * F_{\text {feses }-D W}$ (2)

di mana:

$m_{\text {air }}=$ massa unsur zat hara yang terdapat dalam medium air (g/kg-pakan)

$m_{\text {pakan }}=$ massa unsur zat hara dalam pakan yang ditambahkan ke dalam kolam (g/kg-pakan)

$m_{\text {ikan }}=$ bobot ikan $(\mathrm{g} / \mathrm{kg})$

$m_{\text {feses }}=$ bobot basah unsur zat hara yang diekskresikan oleh ikan (g/kg-feses)

$F C R=$ feed conversion rasio = rasio massa unsur zat hara yang diserap ikan $(\mathrm{g} / \mathrm{kg}$ - 
bobot ikan)

$F_{\text {feses-DW }}=$ faktor konversi untuk mengubah bobot basah feses ikan menjadi bobot kering ( $g$-feses/kg-pakan)

Nilai $F C R$ yang digunakan dalam perhitungan adalah $1,11 \mathrm{~g} / \mathrm{kg}$-bobot ikan (Kamal \& Mair 2005). Sedangkan nilai $F_{\text {feses-DW }}$ yang digunakan adalah 0,214 gfeses/kg-pakan (Rafiee \& Saad 2005). Partisi untuk komponen zat hara nitrogen $(\mathrm{N})$, fosfor (P) dan belerang (S) ditunjukkan pada Tabel 4 (Guimarães et al. 2008, Moccia et al. 2007, Gonzales \& Brown 2006, Köprücü \& Özdemir 2005, Naylor et al. 1999). Dengan menerapkan persamaan (2) maka dapat dihitung laju akumulasi harian zat hara sebagaimana disajikan hasilnya pada Tabel 5 dan secara grafik ditunjukkan pada Gambar 10. Karena belum terdapat baku mutu yang berlaku umum baik air maupun air limbah budidaya perikanan, khususnya budidaya ikan nila, maka digunakan rujukan Peraturan Pemerintah Nomor 82 Tahun 2001 tentang Pengelolaan Kualitas Air dan Pengendalian Pencemaran Air, khususnya peruntukan air Kelas 3. Menurut PP82/2001 tersebut untuk fosfor dan sulfur (sebagai sulfida) ambang batas mutu air Kelas 3 adalah 1 dan 0,002 mg/L. Namun, karena untuk nitrogen (amonia) tidak ditetapkan secara gamblang maka digunakan rujukan 0,05 $\mathrm{mg} / \mathrm{L}$ (Marlina \& Rakhmawati 2016).

Tabel 4. Partisi unsur zat hara dalam pakan, ikan serta feses

\begin{tabular}{ccccc}
\hline \hline \multirow{2}{*}{ No } & Parameter & \multicolumn{3}{c}{ Kandungan dalam } \\
\cline { 3 - 5 } & & $\begin{array}{c}\text { Pakan } \\
(\mathrm{g} / \mathrm{kg} \text {-pakan) }\end{array}$ & $\begin{array}{c}\text { lkan } \\
(\mathrm{g} / \mathrm{kg} \text {-bobot })\end{array}$ & $\begin{array}{c}\text { Feses } \\
(\mathrm{g} / \mathrm{kg} \text {-bobot kering) }\end{array}$ \\
\hline \hline 1 & $\mathrm{~N}$ & 51,80 & 36,23 & 28,30 \\
2 & $\mathrm{P}$ & 6,83 & 0,26 & 6,69 \\
3 & $\mathrm{~S}$ & 2,83 & 2,45 & 0,38 \\
\hline
\end{tabular}

Tabel 5. Akumulasi zat hara dalam air kolam budidaya ikan nila

\begin{tabular}{cccccc}
\hline \multirow{2}{*}{ No } & Parameter & $\begin{array}{c}\text { Laju akumulasi dalam air } \\
\text { kg/hari }\end{array}$ & $\begin{array}{c}\text { P1 } \\
\text { kg/hari }\end{array}$ & $\begin{array}{c}\mathrm{P} 2 \\
\mathrm{~kg} / \mathrm{hari}\end{array}$ & $\begin{array}{c}\mathrm{P} 3 \\
\mathrm{~kg} / \mathrm{h} \text { hri }\end{array}$ \\
\hline \hline 1 & $\mathrm{~N}$ & 0,07 & 0,10 & 0,09 & 0,06 \\
2 & $\mathrm{P}$ & 0,03 & 0,04 & 0,04 & 0,02 \\
3 & $\mathrm{~S}$ & 0,00 & 0,00 & 0,00 & 0,00 \\
\hline
\end{tabular}




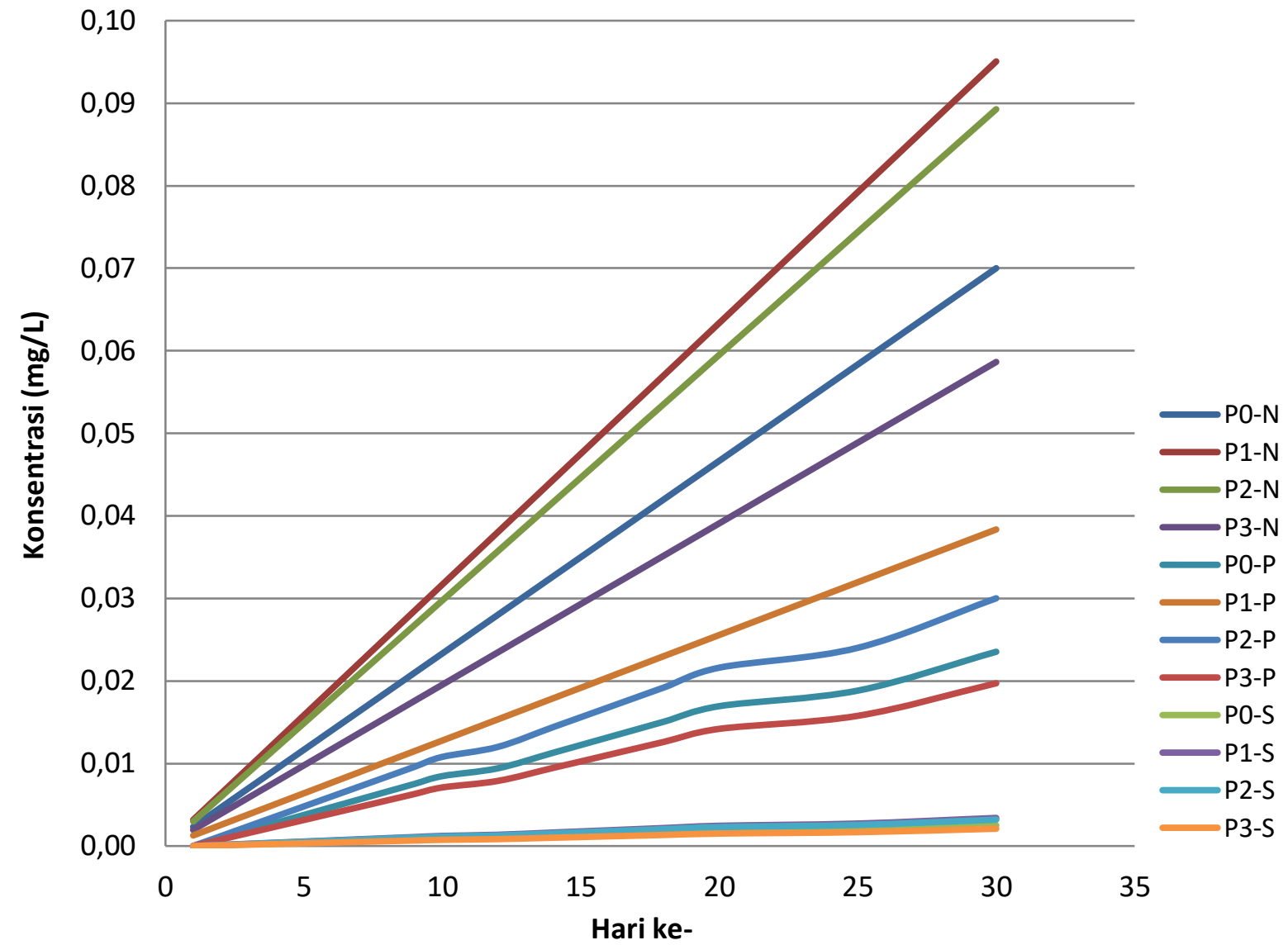

Gambar 10. Lung (curve) akumulasi harian zat hara dalam air kolam budidaya ikan nila

Tabel 6. Hari kesekian di mana tingkat zat hara melampaui batas aman untuk budidaya

\begin{tabular}{cccccc}
\hline \multirow{2}{*}{ No } & \multirow{2}{*}{ Parameter } & \multicolumn{5}{c}{ Hari ke- } \\
\cline { 3 - 6 } & & $\mathrm{P} 0$ & $\mathrm{P} 1$ & $\mathrm{P} 2$ & $\mathrm{P} 3$ \\
\hline \hline 1 & $\mathrm{~N}$ & 20 & 16 & 16 & 25 \\
2 & $\mathrm{P}$ & - & - & - & - \\
3 & $\mathrm{~S}$ & 16 & 12 & 12 & 18 \\
\hline
\end{tabular}

Tabel 7. Kebutuhan air budidaya ikan nila menurut skenario

\begin{tabular}{cccc}
\hline \hline No & Perlakuan & $\begin{array}{c}\text { Operasional kolam } \\
(\text { minggu })\end{array}$ & Volume air total $\left(\mathrm{m}^{3}\right)$ \\
\hline \hline 1 & Konvensional & 1 & 600 \\
2 & P0 & 3 & 200 \\
3 & P1 & 2 & 300 \\
4 & P2 & 2 & 300 \\
5 & P3 & 4 & 150 \\
\hline
\end{tabular}


Tabel 8. Data flux zat hara oleh sistem akar tanaman tomat

\begin{tabular}{ccc}
\hline No & Parameter & $\begin{array}{c}\text { flux } \\
\left(\mathrm{g} / \mathrm{m}^{2} \text {-hari }\right)\end{array}$ \\
\hline \hline 1 & $\mathrm{~N}$ & 0,404 \\
2 & $\mathrm{P}$ & 0,098 \\
3 & $\mathrm{~S}$ & 0,110 \\
\hline
\end{tabular}

Tabel 9. Kemampuan serap dan potensi panen tanaman tomat hidroponik

\begin{tabular}{cccccc}
\hline \hline No & Parameter & flux & $\begin{array}{c}\text { Nutrien diserap } \\
\text { akar } \\
\left(\mathrm{g} / \mathrm{m}^{2} \text {-hari }\right)\end{array}$ & $\begin{array}{c}\text { Nutrien } \\
\text { tersedia } \\
(\mathrm{g})\end{array}$ & $\begin{array}{c}\text { Potensi panen } \\
(\mathrm{g})\end{array}$ \\
\hline \hline 1 & $\mathrm{~N}$ & 0,404 & 404 & 586 & 1 \\
2 & $\mathrm{P}$ & 0,098 & 98 & 237 & 2 \\
3 & $\mathrm{~S}$ & 0,11 & 110 & 25 & 0 \\
\hline
\end{tabular}

Menyimak pola akumulasi zat hara (tabel perhitungan harian disajikan pada lampiran) dalam air kolam budidaya ikan nila maka tampak bahwa untuk 30 hari (seperlima bagian waktu daur budidaya) masa budidaya ikan nila zat hara fosfor masih belum melampaui konsentrasi 1 $\mathrm{mg} / \mathrm{L}$ untuk seluruh skenario pemberian pakan ikan. Tabel 6 menyajikan hari kesekian sejak penebaran benih ikan nila di mana zat hara dalam air kolam mulai melampaui batas aman untuk budidaya ikan nila.

Dari Tabel 6 di atas tampak bahwa untuk perlakuan P3 (tiga hari pemberian pakan satu hari dipuasakan) penurunan mutu air kolam budidaya adalah yang paling lama, yakni kira-kira satu bulan sejak tebar benih ikan nila dalam kolam. Dengan demikian urutan prioritas skenario pergantian air berdasarkan bertahannya mutu air kolam adalah P3 > P0 > P1 = P2. Membandingkan dengan teknik budidaya ikan nila secara konvensional maka kelebihan tiap skenario terkait kebutuhan penggunaan air untuk satu daur budidaya ditunjukkan pada Tabel 7 .

Bilamana sistem akuaponik dijalankan dengan skenario P3 yang membutuhkan volume air paling minimal maka perlu menghitung kemampuan tanaman hidroponik tomat dalam menyerap (absorp) zat hara yang terdapat dalam buangan air kolam budidaya ikan nila. Untuk itu digunakan data fluks zat hara (nutrient flux) sebagaimana disajikan pada Tabel 8 (Peterhans 2015).

Budidaya tanaman tomat secara hidroponik menggunakan spesifikasi sistem sebagaimana berikut ini:

- Kapasitas kolam $=10 \mathrm{~m}^{3}$ (dimensi $5 \mathrm{~m} \times 4 \mathrm{~m} \times 0,5 \mathrm{~m})$

- Periode panen $=50$ hari

- Jumlah unit $=3$

Dengan spesifikasi sistem tersebut dapat dihitung, sebagaimana ditunjukkan pada Tabel 9, kemampuan serap sistem tanaman hidroponik tomat terhadap zat hara yang terdapat dalam buangan air kolam budidaya ikan nila. Dalam tabel tersebut juga disajikan potensi panen tanaman hidroponik tomat berdasarkan tingkat zat hara yang ada dalam air buangan kolam budidaya ikan nila. Hasil perhitungan menunjukkan bahwa konsentrasi fosfor yang ada cukup untuk mendapatkan panen tomat hidroponik sebanyak dua kali sedangkan konsentrasi nitrogen hanya satu kali panen. Namun konsentrasi sulfur yang ada tidak mencukupi sebagai unsur zat hara yang dibutuhkan oleh tanaman tomat.

\section{KESIMPULAN}


Hasil perhitungan menunjukkan bahwa skenario P3, pemberian pakan ikan tiga hari berturutan satu hari dipuasakan, memberikan rasio kebutuhan pakan terhadap bobot ikan total saat panen paling kecil. Hal ini menyebab-kan penurunan mutu air kolam budidaya ikan berjalan lebih lambat daripada skenario yang lain sehingga kekerapan pergantian air dapat menjadi lebih jarang. Kebutuhan volume air budidaya ikan nila dengan skenario P3 juga paling sedikit, 25\% dari kebutuhan air yang menggunakan cara business as usual. Dengan skenario P3 air buangan dapat digunakan untuk melakukan buididaya tanaman tomat secara hidroponik dengan potensi panen sebanyak dua kali berdasarkan tingkat fosfor. Meski demikian terdapat kelemahan skenario P3 dari sudut pandang perolehan biomassa ikan pada saat panen. Dalam hal ini skenario P1 memberikan bobot ikan total saat panen paling besar. 


\section{DAFTAR PUSTAKA}

Avianni N. 2019. Bappenas sebut ada 5 prioritas nasional dalam RKP 2020 https://mediaindonesia.com/read/detail /232829-bappenas-sebut-ada-5prioritas-nasional-dalam-rkp-2020 [Online, diunduh pada 8 Oktober 2019]

Bayu W.N. 2016. Masa panen tanaman hidroponik

http://hidroponikpedia.com/daftarmasa-panen-sayuran-hidroponik/

[Online, diunduh pada 18 Oktober 2019]

Brunner P.H. \& H. Rechberger. 2005. Practical Handbook of Material Flow Analysis. Lewis Publishers

Cohen A., S. Malone, Z. Morris, M. Weissburg \& B. Bras. 2018. Combined fish and lettuce cultivation: an aquaponics Life Cycle Assessment. Proceedia CIRP Vol.69:551-556

Databoks. 2019. Nila dan lele paling banyak dibudidaya di Indonesia https://databoks.katadata.co.id/datapu blish/2016/09/19/nila-dan-lelekomoditas-utama-perikanan-budidayaindonesia

[Online, diunduh pada 1 Oktober 2019]

Daun ljo. 2017. Tanaman apa saja yang cocok untuk akuaponik

http://daunijo.com/tanaman-apa-sajayang-cocok-untuk-akuaponik/

[Online, diunduh pada 18 Oktober 2019]

Gonzales J.M. \& P.B. Brown. 2006. Nile tilapia Oreochromis niloticus as a food source in advanced life support systems:Initial considerations.

Advances in Space Research Journal Vol.38:1132-1137

Guimarães I.G., L.E. Pezzato \& M.M Barros. 2008. Amino acid availability and protein digestibility of several protein sources for Nile tilapia, Oreochromis niloticus. Aquaculture Nutrition Vol.14:396-404

Hartami P., Mukhlis \& Erniati. 2015. Konsumsi harian yang berbeda dari beberapa strain ikan nila (Oreochromis niloticus). Acta Aquatica Vol.2(1):1-7
Kamal A.H.M.M. \& G.C. Mair. 2005. Salinity tolerance in superior genotypes of tilapia, Oreochromis niloticus, Oreochromis mossambicus and their hybrids. Aquaculture Vol.247:189201

Kementerian Kelautan dan Perikanan Republik Indonesia. 2018. Produktivitas Perikanan Indonesia (Bahan presentasi pada Forum Merdeka Barat 9 Kementerian Komunikasi dan Informatika, Jakarta tanggal 19 Januari 2018)

Köprücü, K. \& Y. Özdemir. 2005. Apparent digestibility of selected feed ingredients for Nile tilapia (Oreochromis niloticus). Aquaculture Vol.250:308-316

Kusmini I.I., O.Z. Arifin, F.P. Putri \& Kusdiarti. 2013. Laju pertumbuhan ikan nila BEST (Oreochromis nilotikus) F4 dan F5 hasil seleksi individu. Prosiding Forum Inovasi Teknologi Akuakulrue 2013. pp:563-569

Marie R., M.A. Syukron \& S.S.P. Rahardjo. 2018. Teknik pembesaran ikan nila (Orechromis niloticus) dengan pemberian pakan limbah roti. Jurnal Sumberdaya Alam dan Lingkungan Vol.5(1):1-6

Moccia R., D. Bevan \& G. Reid. 2007. Composition of Fecal Waste from Commercial Trout Farms in Ontario: Macro and Micro Nutrient Analyses and Recommendations for Recycling. Final Report Submitted to the: Ontario Sustainable Aquaculture Working Group Environment Canada

Muhammad F. 2018. Jenis ikan nila unggulan

https://lintar.net/jenis-ikan-nila/

[Online, diunduh pada 11 November 2019]

Naylor S.J., R.D. Moccia \& G.M. Durant. 1999. The Chemical Composition of Settleable Solid Fish Waste (Manure) from Commercial Rainbow Trout Farms in Ontario, Canada. North American Journal of Aquaculture Vol.61:21-26

Nugroho A., E. Arini \& T. Elfitasari. 2013. Pengaruh kepadatan yang berbeda terhadap kelulushidupan dan 
pertumbuhan ikan nilam (Orechromis niloticus) pada sistem resirkulasi dengan filter arang. Journal of Aquaculture Management and Technology Vol.2(3):94-100

Peraturan Pemerintah Nomor 82 Tahun 2001 tentang Pengelolaan Kualitas Air dan Pengendalian Pencemaran Air

Peterhans T. 2015. Aquaponic nutrient model: a daily flow material analysis approach. Master Thesis document. Wageningen University. Agrotechnology and Food Sciences. The Netherlands

Putri T.D., D.P. Priadi \& Sriati. 2015. Dampak usaha perikanan budidaya terhadap kondisi lingkungan dan sosial ekonomi masyarakat pada lahan pasang surut Kabupaten Banyuasin Propinsi Sumatra Selatan. Jurnal Akuakultur Rawa Indonesia Vol.2(1):43-54

Rafiee G. \& C.R Saad. 2005. Nutrient cycle and sludge production during different stages of red tilapia (Oreochromissp.) growth in a recirculating aquaculture system. Aquaculture Vol.244:109-118

Rajagukguk E., Mulyadi \& M.T. Usman. 2018. Pengaruh waktu pemberian pakan terhadap pertumbuhan dan kelulushidupan ikan nila merah (Orechromis niloticus) dengam system resirkulasi. Jurnal Fakultas Perikanan dan Kelautan Universitas Riau 2018

Salsabila M. \& H. Suprapto. 2018. Teknik pembesaran ikan nila (Oreochromis niloticus) di instalasi budidaya air tawar
Pandaan, Jawa Timur. Journal of Aquaculture and Fish Health Vol.7(3):118-123

Sari I.P., Yulisman \& Muslim. 2017. Laju pertumbuhan dan efisiensi pakan ikan nila (Oreochromis niloticus) yang dipelihara dalam kolam terpal yang dipuasakan secara periodik. Jurnal Akuakultur Rawa Indonesia Vol.5(1):45-55

Siregar M. 2016. Eutrofikasi dan limbah pakan dampak polusi budidaya perikanan

https://www.isw.co.id/singlepost/2016/10/29/Eutrofikasi-dan-

Limbah-Pakan-Dampak-Polusi-

Budidaya-Perikanan

[Online, diunduh pada 10 Oktober 2019]

Trubus. 2014. Hidroponik: tinggi produksi, hemat biaya, swarakit (majalah Trubus: Maret 2014)

https://thehijau.com/hidroponik-tinggi-

produksi-hemat-biaya-swarakit/

[Online, diunduh pada 7 Desember 2019]

United Nations. 2019. Sustainable development goals knowledge platform

https://sustainabledevelopment.un.org/

topics/sustainableconsumptionandpro

duction

[Online, diunduh pada 8 Oktober 2019]

Yonida A.D. 2016. Macam-macam model

akuaponik yang banyak digunakan

http://farming.id/macam-macam-

model-akuaponik-yang-banyak-

digunakan/

[Online, diunduh pada 30 September 2019] 
LAMPIRAN DATA PERHITUNGAN AKUMULASI HARIAN ZAT HARA

\begin{tabular}{|c|c|c|c|c|c|c|c|c|c|c|c|c|}
\hline \multirow{4}{*}{ Hari } & \multicolumn{12}{|c|}{ Zat hara } \\
\hline & \multirow{2}{*}{\multicolumn{4}{|c|}{$\begin{array}{c}\text { Nitrogen }\left(\mathrm{NH}_{3}-\mathrm{N}\right), \mathrm{mg} / \mathrm{L} \\
\text { Skenario }\end{array}$}} & \multirow{2}{*}{\multicolumn{4}{|c|}{$\begin{array}{c}\text { Fosfor }\left(\mathrm{PO}_{4}{ }^{3}\right), \mathrm{mg} / \mathrm{L} \\
\text { Skenario }\end{array}$}} & \multirow{2}{*}{\multicolumn{4}{|c|}{$\begin{array}{l}\text { Sulfur }\left(\mathrm{H}_{2} \mathrm{~S}\right), \mathrm{mg} / \mathrm{L} \\
\text { Skenario }\end{array}$}} \\
\hline & & & & & & & & & & & & \\
\hline & P0 & $\mathrm{P} 1$ & P2 & P3 & P0 & P1 & P2 & P3 & P0 & P1 & P2 & P3 \\
\hline 1 & 0,00 & 0,00 & 0,00 & 0,00 & 0,00 & 0,00 & 0,00 & 0,00 & 0,000 & 0,000 & 0,000 & 0,000 \\
\hline 2 & 0,00 & 0,01 & 0,01 & 0,00 & 0,00 & 0,00 & 0,00 & 0,00 & 0,000 & 0,000 & 0,000 & 0,000 \\
\hline 3 & 0,01 & 0,01 & 0,01 & 0,01 & 0,00 & 0,00 & 0,00 & 0,01 & 0,000 & 0,000 & 0,000 & 0,000 \\
\hline 4 & 0,01 & 0,01 & 0,01 & 0,01 & 0,00 & 0,01 & 0,00 & 0,01 & 0,000 & 0,001 & 0,001 & 0,000 \\
\hline 5 & 0,01 & 0,02 & 0,01 & 0,01 & 0,00 & 0,01 & 0,01 & 0,01 & 0,001 & 0,001 & 0,001 & 0,000 \\
\hline 6 & 0,01 & 0,02 & 0,02 & 0,01 & 0,01 & 0,01 & 0,01 & 0,01 & 0,001 & 0,001 & 0,001 & 0,001 \\
\hline 7 & 0,02 & 0,02 & 0,02 & 0,01 & 0,01 & 0,01 & 0,01 & 0,01 & 0,001 & 0,001 & 0,001 & 0,001 \\
\hline 8 & 0,02 & 0,03 & 0,02 & 0,02 & 0,01 & 0,01 & 0,01 & 0,02 & 0,001 & 0,001 & 0,001 & 0,001 \\
\hline 9 & 0,02 & 0,03 & 0,03 & 0,02 & 0,01 & 0,01 & 0,01 & 0,02 & 0,001 & 0,001 & 0,001 & 0,001 \\
\hline 10 & 0,02 & 0,03 & 0,03 & 0,02 & 0,01 & 0,01 & 0,01 & 0,02 & 0,001 & 0,001 & 0,001 & 0,001 \\
\hline 12 & 0,03 & 0,04 & 0,04 & 0,02 & 0,01 & 0,02 & 0,01 & 0,02 & 0,001 & 0,002 & 0,002 & 0,001 \\
\hline 14 & 0,03 & 0,04 & 0,04 & 0,03 & 0,01 & 0,02 & 0,02 & 0,03 & 0,001 & 0,002 & 0,002 & 0,001 \\
\hline 16 & 0,04 & 0,05 & 0,05 & 0,03 & 0,02 & 0,02 & 0,02 & 0,03 & 0,002 & 0,002 & 0,002 & 0,001 \\
\hline 18 & 0,04 & 0,06 & 0,05 & 0,04 & 0,02 & 0,02 & 0,02 & 0,04 & 0,002 & 0,002 & 0,002 & 0,002 \\
\hline 20 & 0,05 & 0,06 & 0,06 & 0,04 & 0,02 & 0,03 & 0,02 & 0,04 & 0,002 & 0,003 & 0,003 & 0,002 \\
\hline 25 & 0,06 & 0,08 & 0,07 & 0,05 & 0,02 & 0,03 & 0,03 & 0,05 & 0,003 & 0,003 & 0,003 & 0,002 \\
\hline 30 & 0,07 & 0,10 & 0,09 & 0,06 & 0,03 & 0,04 & 0,04 & 0,06 & 0,003 & 0,004 & 0,004 & 0,003 \\
\hline
\end{tabular}

